\title{
Arresting Masculinity: Anger, Hybridity and the Reproduction of Phallic Space
}

\author{
Dany Nobus ${ }^{1}$
}

Published online: 12 May 2020

(c) The Author(s) 2020

\begin{abstract}
This paper examines how the signifier of 'toxic masculinity' operates in the contemporary psycho-social landscape of embodied power relations. It is argued that toxic masculinity is a symbolic response to the deep sense of anger people experience owing to the persistent disturbance of reason that characterizes the radically incongruous Thirdspace in which we live. To those who feel disoriented and lost, toxic masculinity is both an imagined cause and a projected solution to the endemic sense of dislocation. As an index of repressive power, self-serving discipline and ruthless ambition, toxic masculinity is held fully responsible by angry 'outsiders' for the ongoing disturbance of reason, whilst the very attribution of the cause of this disturbance to a gendered position of traditional embodied authority simultaneously serves the purpose of changing the hybridity of Thirdspace into more conventional figurations of social imbalance. This explanatory model, which draws both on Edward W. Soja's reflections on the changing spatialities of the human lifeworld and Henri Lefebvre's theory of the (re-)production of (phallic) space, is further employed to address the questions as to why patriarchy persists and whether alternative constellations of governance are feasible.
\end{abstract}

Keywords Anger $\cdot$ Masculinity $\cdot$ Thirdspace $\cdot$ Hybridity $\cdot$ Patriarchy

\section{Introduction}

Once upon a time, a long time ago, so long ago that I cannot even pinpoint exactly when, it would have been unequivocally complimentary for a man to be called a man. Nowadays, being called a man is an insult at best and a derogation at worst. A man is someone who talks in manspeak (usually characterised by an extended series of guttural sounds), who also performs manspeaking, i.e. who unashamedly

\section{Dany Nobus}

dany.nobus@brunel.ac.uk

1 Division of Psychology, College of Health and Life Sciences, Brunel University London, London, UK 
contributes to a conversation amongst women without waiting until he is being spoken to, and who consistently engages in the discursive evil of mansplaining. At the risk of over-simplifying the picture, a 21st century man (not the schizoid type King Crimson were singing about back in 1969, but the 'normal' variety) is unmannerly, self-absorbed, authoritarian, reactionary, disrespectful, bigoted, secretly hoping for the return of page 3 in The Sun newspaper, misogynistic, sex-starved, loud-mouthed, sleazy, ignorant, lazy, arrogant, proud about his beer-belly, physically and emotionally abusive, power-hungry, potentially violent towards everyone apart from himself and his man-mates down the pub, and utterly risible without he himself knowing it. Maybe I am exaggerating, maybe I am painting a caricature, maybe I am just disgruntled about the fact that I was once called out on twitter in a faux apologetic meme as a 'man with a manly view'. Fact of the matter is that in times of \#MeToo campaigns, when white male billionaire besuited businessmen are ruling the world, white male Etonians and Harrovians are enjoying themselves tearing apart economic treaties, and other not-so-white right-wing male populists have no shame in justifying extra-judicial killings, it is not very nice to be called a man with a manly view.

Two decades into the 21st century, (white) masculinity has become a bottomless repository for all that is repulsive in the late capitalist Western world, and the signifier has acquired such a high degree of 'toxicity' that 'toxic masculinity' is almost tautological. In addition, this toxicity is not merely associated with the hegemonic social status of masculinity [9, pp. 183-188], but is meant to capture its very existence as a residual product of patriarchy. However, within the space of this paper I shall not offer a detailed psychoanalytic interpretation of how "men with manly views' have come to represent the foul faces of all types of social inequality, nor of how this 'crisis of masculinity' is deeply affecting scores of young men in search of an identity. Man though allegedly I am, I remain unsure I would be able to 'pull it off' without having recourse to an extensive discussion of how sexual identity politics interact with symbolic and other capital in the wake of a global economic crisis, which would require more than a few pages in an academic journal. Likewise, I shall resist the temptation to critically deconstruct the prevailing meanings of (white) masculinity in contemporary discursive practices, because my own (self-identified or attributed) manhood, not to mention the fact that I can easily be perceived as writing from a white, male privileged position of social and intellectual authority, would make the exercise inherently suspect and thus largely futile. If there is any percentage to be found in a careful dissection of the semantic field in which contemporary masculinity is embedded, the task would have to befall someone whose wardrobe does not contain male sartorial paraphernalia, and who is therefore high above suspicion, lest the outcome be regarded as but an insidious attempt at rehabilitating the tarnished image of man, or resolving the sorry state of 'masculinity in crisis'. Lofty as these aims would have been-some abandoned owing to a lack of space, others discarded owing to an accidental chromosomal excess-I shall restrict myself, here, to some brief (psychoanalytic) reflections on how the signifier of 'toxic masculinity' operates in the contemporary psycho-social landscape of embodied power relations, and on how this prevalent paradigm of modern masculinity connects with contemporary debates on (the future of) patriarchy. Indeed, I believe that contemporary allegations of toxic masculinity are characteristic of a broader social force-field, in 
which toxicity is the new name for a reprehensible amalgamation of moral corruption, systemic exploitation and limitless egomania. It is not only worth investigating, then, how this name circulates and what purpose it serves, but also how it impacts upon those who employ it and those who receive it—as an allegation of perfidy and prodigality, or as a concept of gendered selfhood.

\section{A Brief Anatomy of Anger}

By contrast with the last decade of the 20th century, which has been dubbed 'the age of anxiety' [10], the still relatively young 21 st century could be characterised as the 'age of anger'. All around the world, people young and old are angry, and whereas the majority vents it via social media, peaceful protests, school strikes, public inquiries and critical social movements such as Extinction Rebellion, Global Action for Trans Equality (GATE) and the Swarm Collective, on an almost daily basis it is also manifested in formal complaints, road- and other types of rage, seditious torchlight parades, hate crime and often barbaric, physical interpersonal violence. ${ }^{1}$

For all his emphasis on the death drive [12] and the irreducible discontents in civilization [16], Freud had almost nothing to say about anger. For sure, aggressivity intermittently appeared on his radar, yet this manifestation of the drive must not be confused with the passion or the emotion of anger, as an explosive interior affective state [50, p. 75]. Aggressivity may be motivated by factors other than angeramongst the cardinal sins, lust, envy and greed would probably be the most likely candidates - and anger does not de facto result in aggressivity, especially if the latter term is restricted to instances of hostile or violent behaviour towards others. Perhaps it is testament to Freud's general disregard of anger, or maybe even his visceral fear of it, that his most evocative riff on the subject appeared in an essay on a 16th century statue of a prophet whose historical existence remains disputed. First published anonymously, and allegedly only by virtue of the fact that its methodology bore some resemblance to psychoanalysis, Freud's reading of the Moses of Michelangelo stands out for its persistent refusal to acknowledge the grandiose marble sculpture in San Pietro in Vincoli as a representation of a man filled with wrath (Zorn), who is on the verge of smashing the Tables. ${ }^{2}$ Angry as he may have been at the sight of his apostate people cavorting around the Golden Calf, Freud's Moses is a figure whose respect for the divine laws allows him to freeze his fury and keep his passions in

\footnotetext{
${ }^{1}$ In London, stabbings have become so common that the traumatic impact of yet another young life wasted is almost instantly erased by the shock of a new lethal incident. It is important to note, in this respect, that the seemingly unstoppable surge of knife-crime on the streets of London is not just another epiphenomenon of inner city racism, or a symptom of unemployed metropolitan youth culture. It is indissociably linked to desperate expressions of masculinity amongst the city's socially deprived young men, paired with a search for identity, a desire for community and an urge to be appreciated for personal accomplishments.

${ }^{2}$ On the historical circumstances surrounding the publication of the paper, whose authorship was only known to the members of the 'secret committee' [25, 49] until it was reprinted in Freud's Gesammelte Schriften in 1924, see [29, pp. 363-367] and [19, pp. 314-317]. For critical and occasionally angry analyses of Freud's reading, see for example [1, 3, 30, 36, 42].
} 
check, to the benefit of all mankind [15, pp. 229-230]. Contrary to what the Old Testament suggests, Freud does not make Moses literally break the law in anger when he observes how the people at the foot of Mount Sinai have already broken the law in their shameless worship of a secular idol. As if to suggest that Moses would never be driven to enact what his people have already performed metaphorically in his absence, Freud argues that Moses is capable of saving the law despite his anger, and that the preservation of the law saves him and his people from further wrongdoings. Anger, it is opined here, proceeds from the disintegration of law and order, the fading of a given set of established principles, or the disruption of an accepted mode of thinking, the more so as this 'sense of reason' is attached to someone's psychosocial sense of identity. Where anger erupts, only the maintenance, or the reinstatement of a stabilizing structuring force may reduce its own destructive potential. It is Moses' unwavering loyalty to the word of God that stops him from giving free rein to the fury provoked by the idolatrous Israelites.

Freud's subversive interpretation of Michelangelo's Moses, as a seethingly angry man who remains nonetheless committed to self-restraint, echoes the enduringly captivating observations on anger by the Roman philosopher Seneca. Purportedly written in response to a request from his older brother Novatus, Seneca's De Ira [45] takes its point of departure from the central Stoic premise that human beings need to submit voluntarily to the law of Nature, the supreme sovereign authority which is governed by virtue. As an unruly passion, anger emanates from a mis-interpretation or mis-judgement of reality-in modern therapeutic parlance, we might call it a 'cognitive distortion' - and to mitigate its harmful effects it is better to prevent it from occurring altogether, yet when it does erupt it should be restrained by the power of reason. Although Freud is unlikely to have agreed with the Stoics that human nature is intrinsically virtuous, Seneca's idea that anger is not a key component of the basic human emotional repertoire but a secondary 're-action', and his proposed antagonism between anger and reason, definitely resonate with Freud's comments on 'frozen wrath' in the Moses of Michelangelo [15, p. 229]. Seneca goes on to assert that 'babies and the aged and the sick [infantes senesque et aegri]' are 'most inclined to anger [iracundissimi]', and that 'everything weak is by nature given to complaint [invalidum omne natura querulum est]' [45, p. 26]. He does not explain why this would be the case, but the Stoic celebration of reason and lucid tranquillity makes it easy to infer that it may have something to do with their being more at the mercy of 'unreason', or less recognised as reasonable human beings. Anger thus originates in a disturbance of reason, and only by virtue of reason shall it be contained. When I was outed on twitter as a 'man with a manly view', someone was probably angry at me, because something I had said or done had driven them out of their comfort zone. I am reluctant to claim that they mis-perceived their immediate social reality, but somehow their reason was being suspended in favour of an unruly passion.

If so many people are angry these days, I would venture the hypothesis that it is because they experience the world in which they live as what Baudrillard would have designated, back in the early 1980s, as a pure simulacrum [2, p. 6]. Social institutions have no relation to reality anymore, at least if reality is defined as the normative primary task they are expected to fulfil. Neoliberal rationalities have infiltrated 
each and every aspect of the social sphere, to the point where everything we see and hear seems to have lost its intrinsic value-reduced to the status of an exchangeable commodity in the endless proliferation of late capitalism. ${ }^{3}$ Health care provision is no longer tailored to patient needs, let alone to the development of a personalised treatment programme, but to Key Performance Indicators, Measures of Success and case management protocols. ${ }^{4}$ In the UK, public universities are now also accountable to the Competition and Markets Authority, because they are effectively selling an educational service to potential 'partners in learning', formerly known as students, who are being readied for the job-market. British vice-chancellors brazenly state that their universities are addressing the skills-gap and preparing the workforce of the future, yet over the past decade the proportion of students disclosing a mental health problem to their institutions has quintupled [47]. To address the issue, the Office for Students (the new 'independent' regulator of English universities) called for an investigation by inviting universities to submit competitive project bids to a socalled 'Catalyst Fund'. The consortium of 'educational service providers' winning the competition were given funds for a project on 'Addressing Barriers to Student Success' [28, 41]. The UK acknowledges that there is a student mental health crisis, and so to tackle the problem they are considering 'grading' universities on their capability to deliver enhanced well-being outcomes. I honestly could not make this up, and if it were not so deeply tragic, I would definitely regard it as a tasteless joke. ${ }^{5}$ In the all-encompassing whirlwind of consumerism, people feel crushed, helpless and out of control, and so politicians deviously take advantage of this widespread feeling of dislocation by speaking to their despair, selling them greatness, health, freedom and independence. Virtual space, hyper-reality and post-truth are the new norm. And since the boundaries between inside and outside, public and private, fantasy and reality, sincerity and deception, right and wrong have simultaneously become blurred or abolished, new forms of exploitation and abuse are legion, or the old forms have found themselves new playgrounds.

Drawing on Edward W. Soja's meticulous dissection of post-modern geographies, I would say that people in the Western world now live in a radically incongruous Thirdspace. According to Soja, Thirdspace is where everything comes together: 'subjectivity and objectivity, the abstract and the concrete, the real and the imagined, the knowable and the unimaginable, the repetitive and the differential, structure and agency, mind and body, consciousness and the unconscious, the disciplined and the transdisciplinary, everyday life and unending history' [46, pp. 56-57]. Almost twenty-five years after these words were first written, some additional confluences of conventional dichotomies could probably be added to the list: left and right, East and West, selfhood and otherness, meaning and nonsense, analogue and digital,

\footnotetext{
${ }^{3}$ For an excellent explication of how the steady neoliberal infiltration of the public sphere has effectively led to the imperilment of democracy, see [8].

${ }^{4}$ For the unintended repercussions of performance metrics in medicine and public health care, which are commonly justified with reference to accountability and transparency, see [40, pp. 116-123].

5 In case it is not entirely clear from my description, I shall state it categorically and unequivocally: I am angry too.
} 
high art and popular culture, masculinity and femininity. Insofar as reason relies (or used to rely) on discernment, differentiation and discretion, reason is disturbed. Yet I would consider 21 st century Thirdspace to be radically incongruous, because the complete hybridity of our lifeworld-internal as well as external-also coincides, as Homi Bhabha argued in his seminal work on the location of culture and in other texts $[4,43$, p. 211], with new structures of authority, much less visible than those of yore, which would have been embodied by priests, teachers, medical doctors and law enforcers, but all the more controlling for that. Insofar as contemporary reason is disturbed on account of the intrinsic hybridity of the Thirdspace, the disturbance is counter-balanced and confounded by a socio-political sphere of continuous surveillance, which is materialised in omnipresent CCTV cameras (no one knows whether they really work, because functionality has long since been abandoned as a key deterrent, and defective cameras are much more cost-effective than fully operational ones) and so-called 'low emission zones' (a clever ecological euphemism for the presence of punitive speed control cameras in densely populated areas), but which is much more insidiously enforced through virtual user engagement metrics and countless anonymous policies ranging from 'Quality and Standards' to 'Health and Safety', and from 'Equality and Diversity' to 'Prevent' and 'Dignity at Work'.

I therefore disagree with psychoanalytic theorists who have claimed that we live under the spell of a collapse of the (symbolic) paternal function, resulting in relentless injunctions to enjoy (more) [51, p. 334, 37, 39, 48]. Cultural goods have no doubt become more diverse over the past twenty-five years or so, and corporate institutions have done their best to create increasingly wider ranges of productsfrom the Coca-Cola Life to the tall-double-decaf-hazelnut-latte-with-soy-milk-andmarshmallows-to-take-away-allegedly because they care about customers' 'special needs', but in reality because they only really care about themselves. Some would say that the enjoyment that can be derived from the diversity and availability of these cultural goods is endless - the quantity of enjoyment is directly proportional, then, to the size of the commodity spectrum-yet I cannot help but think that every source of enjoyment also includes its own source of dissatisfaction, and that the more complicated the source of enjoyment is the more extensive the sources of dissatisfaction associated with it must be. There are only so many things one can be dissatisfied about when drinking an ordinary black filter coffee-it is presumably either too weak or too strong-but I really do not want to think about all the things the consumer of the aforementioned coffee-monstrosity could possibly be disgruntled about. If a command to enjoy is pervading the 21 st century, it may perhaps be ascertained in this super-abundance of cultural goods and corporate slogans to

\footnotetext{
6 To give but one example of how anonymous policies may be used to police civil liberties, the University of Reading recently warned its third-year politics undergraduates not to access an essay by the renowned political theorist Norman Geras, which had been listed as 'essential reading' on their module outline, on any personal devices, and to read it only in a 'secure setting', lest they put themselves at risk of being in breach of the UK government's Prevent Strategy, which is designed to identify and report instances of political extremism giving reason for concern as potentially leading to radicalisation [44]. On the ubiquitous monitoring of individual behaviour in cyberspace, see the landmark tome by Zuboff [52].
} 
'enjoy more', but I do not believe it is at all present on a social level. The aforementioned examples of increased surveillance and policing may serve to illustrate this.

Because reason is disturbed rather than collapsing, anger rather than anxiety ensues. For if anxiety, in one of Freud's many and often mutually incompatible statements on the matter, is tantamount to a transformation of free-floating libido [17, pp. 392-411], i.e. psychic sexual energy which is no longer attached or attachable to a concrete object, then the radically incongruous Thirdspace does not put its inhabitants' libido in an object-less state. Much like reason itself, the object(s) to which libido is attached are volatile, inchoate, transient-always in flux, but never completely absent. If anything, people in the industrialised world must live with an excess of readily available objects, none of which particularly stable or solid, each and every one of which no more than a momentary occurrence in time and space. Yet the more we believe that the objects to which we attach our libido and, by extension, our identities will offer lasting pleasure, the more we mis-judge the 'reality' of Thirdspace and the angrier we become. In this case too, Seneca was right.

\section{Masculinity and Phallic Space}

Up until now, I have argued that anger is rooted in a disturbance of reason. In a radically incongruous Thirdspace, this disturbance is exacerbated by the fact that the state of hybridity in which reason finds itself is complemented by a pervasive, yet largely invisible structure of authority. If we accept that form not only follows libido, as Sylvia Lavin once cogently argued [34], but that libido also follows form, i.e. that the distribution of psychic sexual energy is a reflection of the shape of the environment in which it operates, the all but universal state of anger in which the contemporary world is thrown correlates with the inherent volatility of the object in Thirdspace, the more so as citizens mis-represent the reality of this object to themselves and others as a safe and secure investment. In this febrile and forever changing state of affairs, toxic masculinity is both an imagined cause and a projected solution to the endemic sense of dislocation - at least to those who feel disoriented and lost, the disenfranchised and the dispossessed, the disinherited and the disenchanted. As an index of repressive power, self-serving discipline and ruthless ambition, toxic masculinity is held fully responsible by the angry disillusioned 'weaklings' for the ongoing disturbance of reason, whilst the very attribution of the cause of this disturbance to a gendered position of traditional embodied authority also serves the purpose of changing the hybridity of Thirdspace into more conventional figurations of social imbalance.

Undeservedly ignored and sometimes only discarded for its Christian overtones by secular psychoanalysts, the work of René Girard, and especially his mimetic scapegoat theory [24], may provide valuable additional insights here. Expressed in a Girardian key, the radically incongruous Thirdspace, which is characterised by uncontrolled hybridity and an inescapable inceptive disturbance of reason, represents a fundamental 'mimetic crisis', generally as well as individually, in the private as well as in the public sphere, socially as well as psychically. The contemporary state of reason is in crisis, because some of the most important distinctions upon 
which its exercise rests - those between fact and fiction, truth and falsehood, meaning and nonsense, value and worthlessness - are constantly amalgamated in a paraconsistent discursive logic. The crisis is mimetic, because at its most profound level it affects and disrupts human desire, which is according to Girard always taken up in a dual process of imitative mediation: externally, the imitator and the model identify with regard to an object of desire; internally, they enter into a state of rivalry which may become so violent that the very object of desire is eclipsed by it [22]. In order to resolve this mimetic crisis, people living through it have recourse to the identification and exposure of a scapegoat: a person or group in an outsider position, and therefore easily blamed for breaking societal rules, is accused of causing the crisis, which allows the rivalrous parties to bury the hatchet and reunite in a collective battle against the culprit [23, pp. 78-79]. Girard himself acknowledged that there is a distinct echo in all of this of Freud's infamous myth of the murder of the primal father [14, pp. 141-142], yet the principle accords more directly with Freud's observations on social cohesion and interpersonal violence in Civilization and its Discontents, in which he wrote: 'It is always possible to bind together a considerable number of people in love, so long as there are other people left over to receive the manifestations of their aggressiveness' [16, p. 114].

Girard's theory is appealing not only because it documents psycho-social forces that resonate with our contemporary living conditions, as a world-in-anger, but also because its proposed mechanism of the scapegoat, as the common solution to the mimetic crisis, chimes with the way in which this 21 st century world-in-anger responds to its own internal and external dissociations. On at least three points, however, do we need to consider a modification to Girard's mimetic scapegoat theory if we are to employ it as an explanation for the emergence of toxic masculinity as an essential component of the endemic mimetic crisis of the radically incongruous Thirdspace in which we live. First, the relationship between insider and outsider, inasmuch as this dichotomy is still valid and detectable in the hybrid Thirdspace, needs to be reversed. In Girard's model, the generalised mimetic crisis emboldens those in a social majority position to reassemble, close the ranks and collaborate against a culpable outsider. In our current socio-political climate, it is the self-identified or exposed outsiders, or at least those who feel they have somehow lost out and are in a position of secondariness, who reconvene, forge new bonds of solidarity, and join forces against a blameworthy insider. Second, although the scapegoat is still routinely identified as a concrete person or group, it is much more common for the answerable agency to be an abstract concept or principle, which is subsequently saturated with a broad range of physical and other attributes. If sovereign toxic masculinity is to blame for the mimetic crisis of Thirdspace, this attribution applies less to a person or group of people than to a certain quiddity that is indicative of a series of cultural representations and a reprehensible ideology. Third, in Girard's mimetic scapegoat theory, which was originally developed in relation to the fictional space of Western literature but which subsequently gained momentum as a comprehensive account of human social relations, the question concerning the validity of the attribution is rarely posed, but always resolved, if only because the newly found consensus amongst the insiders suffices for the verdict to be passed. In our contemporary Thirdspace, where fake news rules and post-truth is a dominant value, the issue as 
to whether the attribution is valid is always posed, yet rarely resolved, neither by the outsiders who claim to have witnessed it and have been on its receiving end, nor by the allegedly guilty insiders who have been operating under its aegis - although the latter may of course always protest that one cannot prove a negative. It is undoubtedly the case that toxic masculinity exists, in all its abusive realities, and that it has persisted since the halcyon days of the paterfamilias, yet the consensus of the victimised outsiders no longer suffices to validate its occurrence, the less so as the distinction between scientific proof and hazy speculation has become putty in the hands of the ruling elite.

As such, in the era of the radically incongruous Thirdspace, and the anger resulting from the disturbance of reason and the mimetic crisis, toxic masculinity is one way for the outsiders to close the infernal cycle of commodification in which they have been bound up. Apart from generating structure where there was only chaos and disruption, order where there was only dissipation and fluidity, the attribution of toxic masculinity, which may or may not coincide with a material reality of exploitation and abuse, acts as an organising signifier of power, against which the powerless, or the temporarily disempowered outsiders, may vent their anger, and through which they can experience a new sense of community, identity and belonging. In its most elementary form, this attribution reintroduces the most conventional psycho-social spatial arrangement, in which power is transacted between a dominant and a submissive force, to render intelligible and (at least temporarily) suspend the disturbance of reason. In their Hegelian designations, the forces operate as 'master' (Herrschaft) and 'servant' (Knechtschaft) [26, p. 113], which has the distinct disadvantage that they may easily be confused with, or constrained to largely outdated social identities. Pace the lingering associations with a certain eroto-sexual practice, there is nothing wrong in employing the terms domination and submission; after all, given the fact that the attribution originates in the outsiders cum oppressed, unjustifiable and non-consensual domination is very much what is being indicted. However, maybe there is yet another way of articulating the terms of this super-imposed force-field, which would have the added benefit of literally staging the spatial re-distributions of power I am trying to articulate here. It is to say that the dominant is constituted by arrectness (verticality, raised, upright and straight) and the submissive by decubitus (horizontality, lying down, recumbent, supine). Between these two, often visibly recognisable positions in a concrete spatial arrangement, power is transacted from (masculine) emission to (feminine) receptivity, with the caveat that the conventional association of emission with arrectness and receptivity with decubitus may be confounded by other than purely physical variables, such as the explicitly agreed or implicitly adopted flow of speech. ${ }^{7}$

\footnotetext{
7 In a thought-provoking essay on the typical spatial arrangements of the psychoanalytic setting, Diana Fuss and Joel Sanders have taken issue with Luce Irigaray's famous critique of the 'scene of analysis' as an orthogonal pairing of an erect psychoanalyst and a prone patient [27], by arguing that Freud always opens 'himself to the risk of feminization' in that he assumes 'the role of an orifice, a listening ear, while the patient becomes a mouth, an oral transmitter' [18, p. 130].
} 
In any case, as an attributed signifier of (abusive) power, toxic masculinity primarily functions as a linguistic tool for resolving the mimetic crisis in the radically incongruous Thirdspace, whereby the outsiders' anger stemming from the disturbance of reason is not so much tempered, but re-centred on an object that is purportedly more stable and less transient, owing to the prolonged if deplorable history of abusive power-relations from which it emanates. Taking account of the three modifications to Girard's theory of mimetic scapegoating I mentioned above, toxic masculinity is thus an attempt on behalf of the disenfranchised to restore order, which implies that it is simultaneously an indictment and a reproduction of traditional patriarchy, and all the ills and evils it carries along. Using the terminology of Henri Lefebvre's seminal 1974 volume The Production of Space, the attribution of toxic masculinity to the identified disturber of reason exposes as well as reproduces phallic space, which in its most rudimentary appearance involves the distribution of power between powerful arrectness (masculine emission) and powerless decubitus (feminine receptivity). For Lefebvre, phallic space "symbolizes force, male fertility, masculine violence... [but] phallic brutality does not remain abstract, for it is the brutality of political power, of the means of constraint: police, army, bureaucracy" [35, p. 287]. Assuming that my analysis is persuasive, or at least sufficiently plausible for it to be considered worthy of further consideration, at least two key questions remain. Why does our contemporary anger attach itself to a symbolic, yet generic figuration of reprehensible masculinity? And even more importantly, how could we conceive of an alternative to phallic space, and under which conditions would this alternative constitute, if not a reasonable prophylactic strategy for the eruption of a new mimetic crisis, perhaps a feasible therapeutic solution to the sense of angry dislocation it elicits?

Writing in the aftermath of the election of Donald J. Trump to the White House, Carol Gilligan and Naomi Snider dared to ask the impossible question: Why does patriarchy persist, in spite of decade-long widespread campaigns for social equality and women's rights? Although they occasionally conflate patriarchy with hierarchy, and power with authority, their answer is that-over and above the fact that a notable sub-section of the population, namely those men-in-power, evidently benefit from the advantages it bestows upon them-patriarchy fulfils an important psychological function:

Patriarchy's persistence is tied not only to a struggle for power and a contest between different frameworks for living or systems of belief, but also to the tension between our desire for love and our desire to avoid the pain of loss. With its gender binary and hierarchy creating impediments to relational presence and integrity, patriarchy becomes a bastion against the pain of loss. The catch is: it requires a sacrifice of love [21, p. 135].

Deeply influenced by John Bowlby's theory of attachment and loss [5-7], Gilligan and Snider argue that the socio-political restoration and preservation of patriarchy provides relief from the psychological anguish that is associated with the intrinsic vulnerabilities of love. In Freudian terms, allowing oneself to (be in) love requires a certain relinquishment of self-love, and thus the acceptance that a quantum of narcissism will need to be given up in favour of the reorientation of the libido towards 
the external object of love [13, pp. 112-113]. Being in love makes us more vulnerable, vulnerability is tantamount to a reduction of self-love, the resulting experience of loss is painful, and the foundation of patriarchy, which entails a gendering of social imbalances of power, attenuates the affective impact of loss, presumably because it exchanges the human experience of love, and all the emotional quandaries it generates, for a loveless system of domination and submission.

There is a lot to be said in favour of this perspective, yet I am not convinced that patriarchy, which is but another word for toxic masculinity here, effectively dampens down the psychological pain of loss. For one, the 'therapeutic' function of patriarchy may easily be undone by the new plethora of losses it generates in the oppressed, amongst which the loss of a voice may very well be the most important one. In addition, patriarchy is also crucially conditioned by its own structures of love - the unconditional love of the leader, ruler or sovereign-which undoubtedly induces other experiences of vulnerability and pain. I do think that Gilligan and Snider hit the proverbial nail when they aver that patriarchy fulfils an important psychological function, and that precisely because of this it is likely to persist. Yet instead of designating this psychological function as 'therapeutic', insofar as it would alleviate pain, I am more inclined to say it is 'prophylactic', inasmuch as it prevents human desire, which is also driven by loss, from becoming extinguished and therefore lost in and of itself in the overwhelming plenitude of commodified objects, which may also include identity — as the final frontier of mass-market commodification. Echoing Todd McGowan's compelling argument that capitalism continues to dominate-despite the numerous inequalities it creates and despite its vocal opponents-because it mimics the structure of human desire [38], which is mired in a ruthless dynamic of incomplete satisfaction and an equally tenacious anticipation of self-fulfilment, I would propose that toxic masculinity continues to rule, because its fundamental mechanism of domination (arrectness) and submission (decubitus) captures another feature of human desire-the fact that it cannot operate without alienation, i.e. without its having been forced into a state of compulsory dispossession. In other words, the relentless return of toxic masculinity, in its simultaneous attribution as a possible cause of the disorder of reason and as the reproduction of phallic space, reinstates and confirms the structure of human desire as a force flowing from loss. By contrast with Gilligan and Snider, I would argue, then, that patriarchy persists not because it mitigates (the pain of) loss, but because it renders (the pain of) loss possible, which is in itself a necessary precondition for human desire to operate.

As to the second question, which raises the complex issue of a feasible alternative, I remain far less optimistic than Gilligan and Snider, who continue to believe in the revolutionary power of social protest:

We see movements fuelled by the anger of hope: the hope that things will in fact change, that the ruptures in democracy can be repaired, that relationship-however tenuous its hold, however beset by appeals to masculine honor and feminine goodness-does not give way to dominance and submission, violence and silence. These are movements inspired by the conviction that as humans we are capable of reconciliation, that the moral arc of the universe 
bends toward justice, and that in the end the anger of hope will win out over the anger of despair [21, p. 137].

In not sharing these words, heartfelt and inspiring as they may be, I fully accept that someone out there might go on to expose me again as a man with a manly view, the more so as the authors of the cited volume are women and I, at least for the time being, remain just an average man, although probably one who will be perceived as writing from a high-status position of academic prestige. However, Gilligan and Snider's message of love and hope occurs to me as a flagrant contradiction of their own observational premises: patriarchy persists despite social protest, and the intrinsic vulnerabilities of love prompt the preservation of patriarchy. Why would the new waves of protest, which are purportedly animated by the anger of hope, be more effective in the abolition of patriarchy than all the ones that have gone before? Why would the new restorative relationships of justice and reconciliation no longer entail painful experiences of loss, and why would the latter be less intractable than those that gave rise to a renewed call for 'therapeutic' patriarchy?

When it comes to thinking about effective ways for disposing of patriarchy and toxic masculinity, I am much more on Lacan's side when, in a chaotic exchange with students and agitators at the newly established experimental University of Vincennes in December 1969, he proclaimed: 'What you aspire to as revolutionaries is a master. You will get one' [33, p. 207]. The discourse of the master, which is consistent with the discourse of domination and submission, and the distribution of libido in a phallic space, is inescapable, for the pure and simple reason that it is the discourse of the human unconscious, and as such the fundamental discourse of human desire. This does not imply that other discourses are de facto excluded, and Lacan himself identified at least three alternative discursive structures [33, pp. 11-24], yet these other discourses only ever operate with reference and in opposition to the discourse of the master, which reigns supreme. ${ }^{8}$ When, in 1974, Lefebvre unfolded his theory of the (re-)production of phallic space, he at one stage played with the idea of an alternative arrangement of spatial coordinates: 'Is a final metamorphosis called for that will reverse all earlier ones, destroying phallic space and replacing it with a 'uterine' space? We can be sure, at any rate, that this in itself will not ensure the invention of a truly appropriated space, or that of an architecture of joy and enjoyment' [35, p. 410]. For Lefebvre, the mode of production of goods and services within space, of which the capitalist modality is but one example, is in fact easier to transform than the production of space itself, because the latter would require a modification of the controlling agencies and parameters of space, and thus a shift from the relentless (re-)production of things towards the intractable (re-)production of the environment in which these things are produced, which is much more difficult to contemplate, at least in terms of socio-economic and political action. Because

\footnotetext{
${ }^{8}$ Lacan's discourse theory is generally restricted to the four interrelated discourses (of the master, the university, the analyst and the hysteric) he formalised during his seminar of 1969-'70 [33]. However, during a lecture in Milan on 12 May 1972, he coined a fifth discourse, termed the discourse of the capitalist, which potentially allows for an additional three 'social bonds', if the same principle of the 'quarter turn', as outlined in his 1969-'70 seminar, is implemented [32, p. 32].
} 
his intellectual agenda is firmly set on ideological matters, Lefebvre does not consider the extent to which the transformation of phallic space may only be achievable through psychological means, as a mental transformation of the structure of human desire, yet even then it remains to be seen what could be achieved at this level and whether a permanent transformation of the discourse of the master, phallic space and toxic masculinity is at all realistic. For all its ostensible duplication of arrectness and decubitus, the discourse of psychoanalysis, which Lacan conceived as the exact opposite of the master's discourse [33, pp. 35-36], initiates an alternative, generative space for speech and a potential re-restructuring of desire, yet this does not necessarily imply that the discourse of the master will completely disintegrate. Maybe the best we can hope for is that, with or without psychoanalysis, authority and hierarchy no longer by definition lead to (an abuse of) power, that domination and submission are incorporated in a more flexible distribution of libido, and that masculinity's obstinate odium of toxicity is in itself recuperated within the confluence of discursive categories.

Unlike Gilligan and Snider, and much like Lacan and Lefebvre, I therefore do not believe that the question as to why patriarchy persists will one day become obsolete, because (as I have endeavoured to argue) it constitutes the most basic, necessary and sufficient condition for human desire to emerge and sustain itself. At the same time, however, I can envisage a psycho-social constellation in which the conventional forms of patriarchy are balanced against other, alternative configurations of power and less rigid spatial arrangements. I am not advocating, here, a serious reconsideration of the radically incongruous Thirdspace and all its hybridities, because the Thirdspace cannot be disjointed from patriarchy, much less so as it proliferates in its appropriation of the object-world as a series of transient, inchoate commodities. What $I$ have in mind is the invention of new, more open and more accessible spaces for human speech, where (much like in psychoanalysis) the lack and the losses that preside over desire can be re-configured into what Jill Gentile has called a 'feminine law' [20], i.e. a generative, emancipatory structure that activates the crucial 'space between' positions of power, divisions of labour, mechanisms of (in)equality, gender dichotomies etc. In its most radical sense, it would involve the creation of spaces in which priority is given to the voice of desire.

\section{Conclusion}

At this stage, the reader undoubtedly expects me to provide a neat synthesis of the argument I have tried to develop. If I shall refrain from doing so, it is not because I deliberately want to disturb the reader's own sense of reason and potentially attract a new wave of anger, but because I believe that this type of standard, conceptual summary at the end of an academic paper is too facile a conclusion, which is in this case also neither necessary nor warranted given the subtleties and complexities of the symbolic circulation of toxic masculinity I have endeavoured to articulate.

Instead, and at the risk of overstating my case, I would like to add two further points to my argument. The first is that over the past couple of years, and especially since the arrival of a certain blatantly misogynistic and excessively self-absorbed 
man in the most powerful house on the planet, masculinity has acquired strong connotations of perversion, and that the very notion of toxicity, which to many is an undeniable and intrinsic feature of masculinity, resonates with the terminology of perversion, as it is used in common parlance and in 'urban dictionaries': behaviour which deviates from socio-cultural norms of acceptability, especially in terms of sexual conduct. Indeed, it is interesting to observe in this respect how concepts and ideas of perversion have recently shifted from all (sexual) behaviours falling outside the conventional framework of (genital) hetero-normativity to (sexual) behaviours falling firmly within the traditional standards of (sexual) identity. Although the term 'perversion' has long since been replaced with 'paraphilia' in the official psychiatric nomenclature, it has almost invariably been linked to 'disorders' of human sexual behaviour, either because the object of sexual attraction was considered 'abnormal' and/or 'illegal' (say, a child or a non-human animal), or because the sexual activity contravened ethico-legal principles of public decency and consent. In recent times, however, we have witnessed a progressive contraction of these paraphilias of sexual orientation and behaviour, including in the psychiatric textbooks, and this has ushered in-although in this case outside the medical discourse and primarily within the common discursive practices of Western socio-cultural understanding-newly recognized perversions (or paraphilias) of sexual identity. This first shift, from perverse orientation and behaviour towards perverse identity, has thereby generated a second transposition, from perversion being defined as what exceeds or transgresses an established (sexual) norm to its being situated within a certain (sexual) norm, notably that of the stereotypical distribution of gender roles, the standard or "normal' adoption of sexual identity, and the 'garden variety' of identity politics, with all the instances of abusive normativity and sexualised power imbalances this norm entails. Whereas the masculine man was once the epitome of sexual normality, he and his accoutrements have more and more become the emblems of sexual abnormality-perversion or toxicity, depending on the discursive context.

Without wanting to assay or judge the validity of this dual change in 21 st century sexual identity politics, I think it has left an indelible mark on the lived experience of young men growing up in the radically incongruous Thirdspace of ubiquitous hybridisation and pervasive covert surveillance. For sure, the troubles facing contemporary male youth are not entirely new. Before the turn of the last century, the American journalist Susan Faludi already drew attention to the state of (American) male youth in crisis [11]. More than twenty years ago, Faludi already concluded that the prevailing paradigm of modern masculinity obstructs rather than enables young men in finding an adequate solution to the social contradictions they experience on a daily basis. On the one hand, young boys are still expected to take control and be strong, yet at the same time they realise that the world in which they live no longer values honesty, mutual respect, loyalty and integrity. If anything, Faludi's assessment, which came quite a few years before the rise of Islamic terror, mass migration and male toxicity, was deeply premonitory of a social crisis of male sexual identity that has continued to aggravate and expand. The disenfranchised of our current mimetic crisis may be angry, and anger may result in a steady (re-)production of phallic space, yet the unequivocal meanings of predatory power associated with modern masculine sexual identity have no doubt also led to new sources of 
disturbance amongst young men, which perhaps more often than not have found their expression in academic underachievement, hate crime and social delinquency [31]. If masculinity is toxic, there is no reason to believe that its toxicity is not felt by men themselves, or that men are not affected in their own way by how the signifiers of male entitlement and privilege are circulating and structuring our contemporary lifeworld. Let this not be an afterthought, but perhaps a starting-point for a detailed consideration of how toxic masculinity also shapes, and not necessarily in a good way, those of us citizens who tend to identify or be identified as male, without therefore attaching much weight to the signifier of masculinity, and who occasionally feel they must express a bit of a view.

Open Access This article is licensed under a Creative Commons Attribution 4.0 International License, which permits use, sharing, adaptation, distribution and reproduction in any medium or format, as long as you give appropriate credit to the original author(s) and the source, provide a link to the Creative Commons licence, and indicate if changes were made. The images or other third party material in this article are included in the article's Creative Commons licence, unless indicated otherwise in a credit line to the material. If material is not included in the article's Creative Commons licence and your intended use is not permitted by statutory regulation or exceeds the permitted use, you will need to obtain permission directly from the copyright holder. To view a copy of this licence, visit http://creativecommons.org/licen ses/by/4.0/.

\section{References}

1. Albrecht, T. 2014. Subject and object in psychoanalytic criticism: On the interpretative method of Freud's 'The Moses of Michelangelo'. Textual Practice 28 (5): 783-806.

2. Baudrillard, J. 1994. Simulacra and simulation, trans. S. Faria Glaser. Ann Arbor, MI: The University of Michigan Press.

3. Bergstein, M. 2006. Freud's 'Moses of Michelangelo': Vasari, photography, and art historical practice. The Art Bulletin 88 (1): 158-176.

4. Bhabha, H.K. 1994. The location of culture. London-New York: Routledge.

5. Bowlby, J. 1969. Attachment. London: The Hogarth Press.

6. Bowlby, J. 1973. Separation: Anxiety and anger. London: The Hogarth Press.

7. Bowlby, J. 1980. Loss: Sadness and depression. London: The Hogarth Press.

8. Brown, W. 2015. Undoing the demos: Neoliberalism's stealth revolution. New York: Zone Books.

9. Connell, R.W. 1987. Gender and power: Society, the person and sexual politics. Cambridge: Polity Press.

10. Dunant, S., and R. Porter (eds.). 1996. The age of anxiety. London: Virago.

11. Faludi, S. 1999. Stiffed: The betrayal of the modern man. London: Chatto and Windus.

12. Freud, S. 1955. Beyond the pleasure principle, trans. J. Strachey. In The standard edition of the complete psychological works of Sigmund Freud, Vol. 18. ed. J. Strachey. London: The Hogarth Press and the Institute of Psycho-Analysis.

13. Freud, S. 1955. Group psychology and the analysis of the ego, trans. J. Strachey. In The standard edition of the complete psychological works of Sigmund Freud, Vol. 18. ed. J. Strachey. London: The Hogarth Press and the Institute of Psycho-Analysis.

14. Freud, S. 1958. Totem and taboo, trans. J. Strachey. In The standard edition of the complete psychological works of Sigmund Freud, Vol. 13. ed. J. Strachey. London: The Hogarth Press and the Institute of Psycho-Analysis.

15. Freud, S. 1958. The Moses of Michelangelo, trans. J. Strachey. In The standard edition of the complete psychological works of Sigmund Freud, Vol. 13. ed. J. Strachey. London: The Hogarth Press and the Institute of Psycho-Analysis. 
16. Freud, S. 1961. Civilization and its discontents, trans. J. Strachey. In The standard edition of the complete psychological works of Sigmund Freud, Vol. 21. ed. J. Strachey. London: The Hogarth Press and the Institute of Psycho-Analysis.

17. Freud, S. 1963. Introductory lectures on psycho-analysis, trans. J. Strachey. In The standard edition of the complete psychological works of Sigmund Freud, Vols. 15/16. ed. J. Strachey. London: The Hogarth Press and the Institute of Psycho-Analysis.

18. Fuss, D., and J. Sanders. 1996. Berggasse 19: Inside Freud's office. In Stud: Architectures of masculinity, ed. J. Sanders. Princeton, NJ: Princeton Architectural Press.

19. Gay, P. 1988. Freud: A life for our time. New York-London: W. W. Norton \& Company.

20. Gentile, J. 2016. Feminine law: Freud, free speech, and the voice of desire. London: Karnac Books.

21. Gilligan, C., and N. Snider. 2018. Why does patriarchy persist?. Cambridge-Medford, MA: Polity Press.

22. Girard, R. 1966. Deceit, desire, and the novel: Self and other in literary structure, trans. Y. Freccero. Baltimore-London: The Johns Hopkins University Press.

23. Girard, R. 1977. Violence and the sacred, trans. P. Gregory. Baltimore-London: The Johns Hopkins University Press.

24. Girard, R. 1986. The scapegoat, trans. Y. Freccero. Baltimore-London: The Johns Hopkins University Press.

25. Grosskurth, Ph. 1991. The secret ring: Freud's inner circle and the politics of psycho-analysis. Reading, MA: Addison-Wesley.

26. Hegel, G. W. F. 2018. The phenomenology of spirit, trans. T. Pinkard. Cambridge: Cambridge University Press.

27. Irigaray, L. 1989. The gesture in psychoanalysis, trans. E. Guild. In Between feminism and psychoanalysis, ed. T. Brennan. London-New York: Routledge.

28. Johnson, K. 2017. Catalyst fund: Addressing barriers to student success. https://www.heacademy. ac.uk/system/files/downloads/hefce_kirstyjohnson_slides.pdf. Accessed April 14, 2019.

29. Jones, E. 1955. The life and work of Sigmund Freud. Vol. 2. Years of maturity (1901-1919). New York: Basic Books.

30. Karpowitz, S.A. 1987. 'The love child': Freud's essay on the Moses of Michelangelo. The Psychoanalytic Review 74 (3): 333-345.

31. Kimmel, M. 2018. Healing from hate: How young men get into-and out of -violent extremism. Los Angeles-London: The University of California Press.

32. Lacan, J. 1978. Du discours psychanalytique. In Lacan in Italia 1953-1978/En Italie Lacan, ed. G.B. Contri. Milano: La Salamandra.

33. Lacan, J. 2007. The seminar. Book XVII: The other side of psychoanalysis (1969-'70), ed. J.-A. Miller, trans. R. Grigg. New York: W. W. Norton \& Company.

34. Lavin, S. 2004. Form follows libido: Architecture and Richard Neutra in a psychoanalytic culture. Cambridge, MA-London: The MIT Press.

35. Lefebvre, H. 1991. The production of space, trans. D. Nicholson-Smith. Malden, MA-Oxford: Blackwell.

36. Macmillan, M., and P. Swales. 2003. Observations from the refuse-heap: Freud, Michelangelo's Moses, and psychoanalysis. American Imago 60 (1): 41-104.

37. McGowan, T. 2004. The end of dissatisfaction? Jacques Lacan and the emerging society of enjoyment. Albany, NY: State University of New York Press.

38. McGowan, T. 2016. Capitalism and desire: The psychic cost of free markets. New York: Columbia University Press.

39. Melman, Ch. 2002. L'homme sans gravité. Jouir à tout prix. Paris: Denoël.

40. Muller, J.Z. 2018. The tyranny of metrics. Princeton, NJ-London: Princeton University Press.

41. Office for Students. 2017. Implementing a strategic approach to mental wellbeing in higher education https://www.officeforstudents.org.uk/advice-and-guidance/promoting-equal-opportunities/addre ssing-barriers-to-student-success-programme/university-of-the-west-of-england/. Accessed April 14, 2018.

42. Penney, J. 2016. 'That despotic finger': Traces of the act in Freud's 'The Moses of Michelangelo'. Parallax 22 (4): 438-457.

43. Rutherford, J. 1990. The third space: Interview with Homi Bhabha. In Identity: Community, culture, difference, ed. J. Rutherford. London: Lawrence and Wishart. 
44. Scripps, T. 2018. Britain: Reading University flags article on 'Ethics of Revolution' under antiterror policy, https://www.wsws.org/en/articles/2018/11/17/brex-n17.html. Accessed December 25, 2019.

45. Seneca. 2010. On anger. In Anger, mercy, revenge, trans. R. A. Kaster and M.C. Nussbaum. Chicago-London: The University of Chicago Press.

46. Soja, E.W. 1996. Thirdspace: Journeys to Los Angeles and other real-and-imagined places. Malden, MA-Oxford: Blackwell.

47. Thorley, C. 2017. Not by degrees: Improving student mental health in the UK's universities. https:// www.ippr.org/research/publications/not-by-degrees. Accessed May 29, 2019.

48. Verhaeghe, P. 2000. The collapse of the function of the father and its effects on gender roles. In Sexuation, ed. R. Salecl. Durham, NC-London: Duke University Press.

49. Wittenberger, G. 1995. Das 'Geheime Komitee' Sigmund Freuds. Institutionalisierungs-prozesse in der Psychoanalytischen Bewegung zwischen 1912 und 1927. Tübingen: Diskord.

50. Woodward, K. 1996. Anger and anger: From Freud to feminism. In Freud and the passions, ed. J. O’Neill. University Park, PA: Penn State University Press.

51. Žižek, S. 1999. The ticklish subject: The absent centre of political ontology. London-New York: Verso.

52. Zuboff, S. 2018. The age of surveillance capitalism: The fight for a human future at the new frontier of power. London: Profile Books.

Publisher's Note Springer Nature remains neutral with regard to jurisdictional claims in published maps and institutional affiliations. 